Carlo Cattani, Hari M. Srivastava, Xiao-Jun Yang (Eds.)

Fractional Dynamics 

Carlo Cattani, Hari M. Srivastava, Xiao-Jun Yang (Eds.)

\section{Fractional Dynamics}

Managing Editor: Agnieszka Bednarczyk-Drąg

Language Editor: Nick Rogers 
Published by De Gruyter Open Ltd, Warsaw/Berlin

Part of Walter de Gruyter GmbH, Berlin/Munich/Boston

\section{(cc) BY-NC-ND}

This work is licensed under the Creative Commons Attribution-NonCommercial-NoDerivs 3.0 license, which means that the text may be used for non-commercial purposes, provided credit is given to the author. For details go to http://creativecommons.org/licenses/by-nc-nd/3.0/.

(C) 2015 Carlo Cattani, Hari M. Srivastava, Xiao-Jun Yang and chapters' contributors, published by de Gruyter Open

ISBN 978-3-11-047208-0

e-ISBN 978-3-11-047209-7

Bibliographic information published by the Deutsche Nationalbibliothek The Deutsche Nationalbibliothek lists this publication in the Deutsche Nationalbibliografie; detailed bibliographic data are available in the Internet at http://dnb.dnb.de.

Managing Editor: Agnieszka Bednarczyk-Drąg

Language Editor: Nick Rogers

www.degruyteropen.com

Cover illustration: @ Thinkstock/3quarks 